\title{
CB1 receptor antagonist rimonabant protects against chronic intermittent hypoxia-induced renal injury in rats
}

\author{
Li Zhao', Tao Liu', Zhan-jun Dou', Mei-ting Wang ${ }^{1}$, Zi-xuan Hu${ }^{1}$ and Bei Wang ${ }^{2^{*}}$
}

\begin{abstract}
Background: Obstructive sleep apnoea (OSA) induced chronic kidney disease is mainly caused by chronic intermittent hypoxia $(\mathrm{ClH})$. Our study investigate the mechanism underlying $\mathrm{ClH}$-induced renal damage and whether the cannabinoid receptor 1 (CB1R) antagonist rimonabant (Ri) alleviates $\mathrm{ClH}$-induced renal injury.
\end{abstract}

Methods: Male Sprague-Dawley rats were randomly divided into five groups: one normal control (NC) group, two chronic intermittent hypoxia $(\mathrm{ClH})$ groups, and two $\mathrm{ClH}+$ Ri groups. Rats in the $\mathrm{NC}$ groups were exposed to room air, while the $\mathrm{ClH}$ groups were exposed to a $\mathrm{ClH}$ environment for 4 weeks (4w $\mathrm{ClH}$ group) and 6 weeks ( $6 \mathrm{w} \mathrm{ClH}$ group), respectively. Additionally, rats in the $\mathrm{ClH}+$ Ri groups were administered $1.5 \mathrm{mg} / \mathrm{kg} /$ day Ri for 4 weeks ( $4 \mathrm{w}$ $\mathrm{ClH}+\mathrm{Ri}$ group) and 6 weeks ( $6 \mathrm{w} \mathrm{ClH}+\mathrm{Ri}$ group), respectively. Following this, the rats were euthanized and kidneys were excised for downstream analysis. In the renal tissues, the morphological alterations were examined via haematoxylin eosin (HE) staining and periodic acid schiff (PAS) staining, CB1R, Fis1, Mfn1, and p66Shc expression was assessed through western blot and immunohistochemistry, and the mitochondrial ultrastructural changes in kidney sections were assessed by electron microscopy.

Results: CB1R expression in the $4 \mathrm{w}$ and $6 \mathrm{w} \mathrm{ClH}$ groups was significantly elevated, and further increased with prolonged hypoxia; however, Ri prevented the increase in ClH-induced CB1R expression. Fis1 and p66Shc expression in the $\mathrm{ClH}$ groups were increased, but Mfn1 expression decreased. Ri decreased Fis1 and p66Shc expression and increased Mfn 1 expression. Renal damage in the $4 \mathrm{w}$ or $6 \mathrm{w} \mathrm{ClH}+\mathrm{Ri}$ group was evidently improved compared with that in the $4 \mathrm{w}$ or $6 \mathrm{w} \mathrm{ClH}$ group. CB1R expression was positively correlated with Fis 1 and p66Shc and negatively correlated with Mfn1. Meanwhile, electron microscopy showed that the percentage of fragmented mitochondria in the tubular cells in each group was consistent with the trend of CB1R expression.

Conclusion: $\mathrm{ClH}$ causes endocannabinoid disorders and induces abnormal mitochondrial dynamics, resulting in renal injury. Treatment with CB1R antagonists reduces $\mathrm{ClH}$-induced renal damage by inhibiting dysregulated renal mitochondrial dynamics.

Keywords: Obstructive sleep apnoea, Chronic intermittent hypoxia, Cannabinoid receptor system 1;renal injury; mitochondrial dynamics, Rimonabant

\footnotetext{
*Correspondence: myemaila@qq.com

${ }^{2}$ The Second Hospital of Shanxi Medical University, No. 382, Wuyi Road,

Taiyuan 030001, Shanxi Province, People's Republic of China

Full list of author information is available at the end of the article
}

C C The Author(s). 2021 Open Access This article is licensed under a Creative Commons Attribution 4.0 International License, which permits use, sharing, adaptation, distribution and reproduction in any medium or format, as long as you give appropriate credit to the original author(s) and the source, provide a link to the Creative Commons licence, and indicate if changes were made. The images or other third party material in this article are included in the article's Creative Commons licence, unless indicated otherwise in a credit line to the material. If material is not included in the article's Creative Commons licence and your intended use is not permitted by statutory regulation or exceeds the permitted use, you will need to obtain permission directly from the copyright holder. To view a copy of this licence, visit http://creativecommons.org/licenses/by/4.0/ The Creative Commons Public Domain Dedication waiver (http://creativecommons.org/publicdomain/zero/1.0/) applies to the data made available in this article, unless otherwise stated in a credit line to the data. 


\section{Background}

Obstructive sleep apnoea (OSA) is one of the most common sleep respiratory disorders that may present with or without symptoms. Approximately close to one billion people are affected, with the prevalence exceeding $50 \%$ in some countries [1]. The pathogenesis of OSA is characterised by repeated upper airway obstruction, which causes partial or whole upper airway closure leading to apnoea and arousal. Chronic intermittent hypoxia $(\mathrm{CIH})$ is a central dominant feature of OSA [2], and produces serious damage, which resembles that caused by ischaemia-reperfusion injury [3]. Eventually, $\mathrm{CIH}$ is recognized as an independent risk factor for multiple diseases, including coronary heart disease, hypertension, pulmonary heart disease, pulmonary embolism, Alzheimer's disease, Parkinson's syndrome and stroke [4-9]. Increasing evidence from the past two decades indicates that patients with untreated OSA have increased risk of advanced chronic kidney disease (CKD) [10]. Recent studies revealed that OSA contributes to CKD via intrarenal hypoxia [11]. Developing a new therapeutic approach for OSA-induced CKD can have significant implications for clinical practice and reduce the population health burden [12].

Recent studies showed that $\mathrm{CIH}$ could cause target organ damage by regulating mitochondrial function [13, 14]. Tubular epithelial cells have enriched mitochondria due to high energy demand. Thus, the relevance of mitochondria in the pathogenesis of kidney disease has been extensively investigated [15]. Previous studies indicate that mitochondrial impairment and mitochondrialderived oxidative stress substantially contribute to tubular cell injury and induces apoptosis in kidney disease $[16,17]$. Mitochondria are dynamic organelles and are a major source reactive oxygen species (ROS) production. Excessive ROS leads to oxidative stress and mitochondrial dysfunction, leading to cell ageing, injury, and apoptosis [18]. Mitochondria constantly undergo fission and fusion to maintain a healthy mitochondrial pool. These mitochondrial dynamics are finely regulated by the pro-fusion mitofusins, Mfn and OPA1, and the profission proteins, Drp1 and Fis1. Excessive fusion or division inhibits sufficient mitochondrial ATP production, leading to cell damage and apoptosis [19]. Mitochondrial fragmentation is a morphological change and an early critical process contributing to mitochondrial membrane leakage and consequent cell death [16]. P66Shc is an adaptor protein belonging to the ShcA family, and may modulate mitochondrial pathobiology in the kidney [20, 21]. Some studies show that p66Shc activation and phosphorylation induces mitochondrial fragmentation, increases interactions between fission proteins and apoptogenic factors, and activates downstream apoptotic pathways [22].
Identifying molecules in $\mathrm{CIH}$ that modulate mitochondrial dynamics and cause functional disturbances in kidney disease is imperative for the implementation of therapeutic strategies. Recent studies provide new insights into cannabinoid receptor 1 (CB1R), which affects mitochondrial function through the regulation of mitochondrial dynamics in the kidney. Further, CB1R activation leads to excessive mitochondrial fracture, and CB1R knockdown in mouse proximal tubule cells have reduced mitochondrial fragmentation and dysfunction [23]. CB1R is a G-protein coupled receptor, and is part of the endocannabinoid (EC) system [24]. EC signalling regulates various physiological functions in vivo [25]. CB1R is expressed in several tissues such as adipose tissue, liver, skeletal muscle, and kidney. In renal tissue, CB1R is localised in podocytes, mesangial cells, proximal tubules, and distal tubules [26]. Previous studies suggest that CB1R is upregulated in human kidney disease, leading to renal hemodynamic abnormalities and dysfunction, oxidative stress, inflammation, and renal fibrosis, which play an important role in kidney disease [27-29]. Currently, CB1R antagonists have been used to inhibit CB1R overexpression in animal experiments, but whether these antagonists can alleviate or prevent $\mathrm{CIH}$ mediated renal injury is unclear.

We hypothesised that OSA may cause target organ damage via abnormal regulation of mitochondrial dynamics, which may be regulated by the ECs. Therefore, we established an OSA-CIH rat model and investigated how $\mathrm{CIH}$ influences renal tissue mitochondrial dynamics. We examined p66Shc, Fis1, and Mfn1 expression in renal tissue to assess the mitochondrial dynamics. Next, we investigated the changes in CB1R expression in our OSA-CIH model after the administration of rimonabant (Ri), a CB1R antagonist. Finally, we compared kidney damage and the expression of mitochondrial dynamics factors between the $\mathrm{CIH}+\mathrm{Ri}$ and $\mathrm{CIH}$ groups to determine whether CB1R could be a therapeutic target that could relieve or prevent $\mathrm{CIH}$-mediated renal injury.

\section{Methods \\ Experimental animals}

Forty healthy male Sprague-Dawley rats $\left(450-500 \mathrm{~g}, 8_{-}\right.$ 10 weeks old) were purchased from the Shanxi Medical University Animal Center, China. The rats were housed under standard conditions at $22-24^{\circ} \mathrm{C}$ and a $12 \mathrm{~h}$ light/ dark cycle. Animal care was in compliance with the legal requirements and guidelines approved by the Ethics Committee for Animal Facility of Shanxi Medical University. All efforts were made to minimise animal suffering.

The rats were randomly divided into five groups with eight rats each: one normal control (NC) group, two chronic intermittent hypoxia $(\mathrm{CIH})$ groups, and two 
$\mathrm{ClH}+\mathrm{Ri}$ groups. Rats in the NC group breathed room air. Rats in the $\mathrm{CIH}$ groups experienced intermittent hypoxia (see below) for 4 (4w $\mathrm{CIH}$ group) or 6 weeks (6w $\mathrm{ClH}$ group). The rats in the $\mathrm{CIH}+\mathrm{Ri}$ groups were given a daily intraperitoneal injection of $1.5 \mathrm{mg} / \mathrm{kg} \mathrm{Ri}$ for 4 (4w CIH + Ri group) or 6 weeks (6w CIH + Ri group).

\section{$\mathrm{ClH}$ model}

A hypoxic control animal experiment system A84 (BioSpherix, Parish, NY, USA) was used to produce the hypoxic environment. A gas control system was used to regulate oxygen and nitrogen flow into the chamber. Ambient oxygen was servo-controlled to generate intermittent hypoxia. During a 2-mincycle, nitrogen was pumped into the chamber at a fixed rate to reach $8 \%$ fraction of inspired oxygen $\left(\mathrm{FiO}_{2}\right)$ within $30 \mathrm{~s}$. Then, compressed air was introduced into the chamber at 10 $\mathrm{L} / \mathrm{min}$ to achieve $21 \% \mathrm{FiO}_{2}$ within $50 \mathrm{~s}$. Compressed air flow was reduced to $5 \mathrm{~L} / \mathrm{min}$ to maintain the level of $21 \%$ oxygen for the remaining $40 \mathrm{~s}$ per cycle. Rats were placed into the chamber for 30 cycles per h, $8 \mathrm{~h}$ per day, for four or six consecutive weeks. Rats in the NC group were housed in the chamber with $21 \% \mathrm{FiO}_{2}$ for the entire experiment. Rats in the $\mathrm{CIH}+\mathrm{Ri}$ groups received a daily intraperitoneal $\mathrm{Ri}$ injection prior to placement into the chronic intermittent low-oxygen chamber. The oxygen concentration in the chambers was verified using a portable oxygen analyser, and an electrode was inserted into the chamber to confirm all oxygen content changes [30].

\section{Haematoxylin and eosin staining}

After 4 or 6 weeks, the renal tissues of the rats were collected and placed in $4 \%$ paraformaldehyde for $24 \mathrm{~h}$. The fixed renal tissues were dehydrated with gradient alcohol, embedded in paraffin, and made into $4 \mu \mathrm{m}$ thick pathological sections. The dried slices were immersed in xylene I/II/III in sequence for $10 \mathrm{~min}$ each, then absolute ethanol, 95, 80, 70\% ethanol for $7 \mathrm{~min}$ each, and washed with water for $5 \mathrm{~min}$. The slices were stained in haematoxylin for $5 \mathrm{~min}$ and washed with water for $5 \mathrm{~min}$, differentiated by $1 \%$ hydrochloric acid in alcohol for $5 \mathrm{~s}$ and rinsed with water for $1 \mathrm{~min}$, counterstained with $1 \%$ eosin for $10 \mathrm{~s}$ and then washed for $1 \mathrm{~min}$. They were immersed in 70, 80, 95\% and absolute ethanol each for $2 \mathrm{~min}$, then immersed in xylene I/II for $5 \mathrm{~min}$ each. Finally, once the sections were naturally dried, they were sealed with neutral gum, and imaged with a light microscope (Olympus, Tokyo, Japan).

\section{Periodic acid schiff staining}

Firstly, the tissue slices were routinely dewaxed to water, oxidized with $10 \%$ periodic acid solution for $10 \mathrm{~min}$, cleaned with distilled water, then put into Schiff dye solution for $15 \mathrm{~min}$, washed with running water for 5 min, stained with hematoxylin for $3 \mathrm{~min}$, washed with running water for $5 \mathrm{~min}$, and then dehydrated, transparent and sealed with resin.

Using a previously reported scoring system [31], we assigned histopathological scores. Histological changes due to tubular necrosis were quantitated by calculating the percentage of tubules in cell necrosis, loss of brush border, cast formation, and tubule dilatation as follows: 0 , none; $1, \leq 10 \% ; 2,11-25 \% ; 3,26-45 \% ; 4,46-75 \%$; and 5 , $>76 \%$. At least 10 fields $(\times 200)$ were reviewed for each slide.

\section{Electron microscopy}

Kidney tissues $(1 \mathrm{~mm} 3)$ were cuted by a sharp blade quickly within 1-3 min processed for further fixation. And then wash the tissues using 0.1 M PB ( $\mathrm{pH}$ 7.4) for 3 times, 15 min each. Tissues avoid light post fixed with $1 \%$ OsO4 in $0.1 \mathrm{MPB}(\mathrm{pH} 7.4)$ for $2 \mathrm{~h}$ at room temperature, and rinsed in $0.1 \mathrm{M} \mathrm{PB}$ ( $\mathrm{pH}$ 7.4) for 3 times, $15 \mathrm{~min}$ each. The tissues were successively dehydrated with gradient alcohol for 20 min each time, 100\% acetone twice, $15 \mathrm{~min}$ each time. Then, resin penetration and embedding at $37^{\circ} \mathrm{C}$, insert the tissues into the pure EMBed 812, and keep in $37^{\circ} \mathrm{C}$ oven overnight. The embedding models were moved into $65^{\circ} \mathrm{C}$ oven to polymerize for more than $48 \mathrm{~h}$, and were cut to $60-80$ $\mathrm{nm}$ thin on the ultra microtome, then the tissues were fished out onto the 150 meshes cuprum grids with formvar film. Then $2 \%$ uranium acetate saturated alcohol solution avoid light staining for $8 \mathrm{~min}$, rinsed in $70 \%$ ethanol for 3 times and then rinsed in ultra pure water for 3 times. 2.6\% Lead citrate avoid $\mathrm{CO}_{2}$ staining for 8 min, and then rinsed with ultra pure water for 3 times. After dried by the filer paper, the cuprum grids were put into the grids board and dried overnight at room temperature. At last, the cuprum grids are observed under TEM $120 \mathrm{kv}$ (HITACHI, Tokyo, Japan) and take images.

To determine mitochondrial fragmentation, the length of mitochondria in 8 randomly selected tubular cells from each group ( $>100$ mitochondria per cell) were measured. The mitochondrion having length $>2 \mu \mathrm{m}$ were considered filamentous and those with $<1 \mu \mathrm{m}$ and spherical configuration were designated as fragmented [21].

\section{Immunohistochemistry}

The renal sections were dried in an incubator at $65^{\circ} \mathrm{C}$ for $20 \mathrm{~min}$, deparaffinised with xylene I/II/III for $10 \mathrm{~min}$ each, rehydrated in absolute ethanol, 95, 80, 70\% ethanol each for $7 \mathrm{~min}$, and immersed in water for $5 \mathrm{~min}$ each. Then, sections were placed in EDTA ( $\mathrm{pH}$ 8.0) and heated in a microwave for $2.5 \mathrm{~min}$ for antigen retrieval. Three 
percent hydrogen peroxide solution was evenly dropped onto the tissue section, covered with a wet lid, and treated with dark treatment for $15 \mathrm{~min}$ to inactivate endogenous peroxidase. Samples were washed twice in PBS for 5 min and blocked with 10\% normal goat serum in PBS at $25 \pm 1^{\circ} \mathrm{C}$ for $30 \mathrm{~min}$. The sections were stained overnight at $4{ }^{\circ} \mathrm{C}$ with rabbit anti-rat anti-CB1R (1:100), anti-Mfn1 (1:100), anti-Fis1 (1:100), and anti-p66Shc (1: 50; Santa Cruz Biotechnology, Dallas, TX, USA). Then, the sections were incubated with biotinylated goat antirabbit secondary antibody $(1: 100$, Santa Cruz Biotechnology), for $40 \mathrm{~min}$ at $37^{\circ} \mathrm{C}$. Diaminobenzidine (DAB) was used to develop the colour for $5 \mathrm{~min}$, and the reaction was quenched with distilled water. Then, the sections were incubated in haematoxylin staining solution for $15 \mathrm{~s}$, rinsed with water for $5 \mathrm{~min}$, and incubated acid alcohol. Finally, tissue samples were dehydrated with graded ethanol $(95,100 \%)$ for $2 \mathrm{~min}$ each, cleared with xylene I/II three times for $2 \mathrm{~min}$ each, and mounted. Samples were imaged with a scanscope CS2 digital pathological scanning system (Leica Biosystems, Wetzlar, Germany) to analyse CB1R, p66Shc, Fis1, and Mfn1 expression in renal tissues.

\section{Western blotting analysis}

Whole kidneys were lysed in lysis buffer and centrifuged at $14000 \mathrm{~g}$ for $20 \mathrm{~min}$ at $4^{\circ} \mathrm{C}$. The supernatant was then collected. Nuclear and cytosolic renal proteins were extracted using a protein extraction kit (Invitrogen, Carlsbad, CA, USA) according to manufacturer's instructions. Protein concentration was determined using a BCA protein assay kit. Total protein $(50 \mu \mathrm{g})$ was separated during $12 \%$ SDS polyacrylamide gel electrophoresis. Separated proteins were transferred to polyvinylidene difluoride membranes (Millipore, Burlington, USA) using a semidry transfer blotting apparatus. The membranes were incubated with primary antibodies for $18 \mathrm{~h}$ at $4{ }^{\circ} \mathrm{C}$. The primary antibodies included rabbit anti-rat anti-CB1R (1: 500) anti-p66shc (1:500), anti-Fis1 (1:500), anti-Mfn1 (1: 500; Santa Cruz Biotechnology). After washing with TBST, the membranes were incubated with the horseradish peroxidase-conjugated secondary antibody goat anti-rabbit (1:5000 Santa Cruz Biotechnology, USA) for $60 \mathrm{~min}$ at $25 \pm 1{ }^{\circ} \mathrm{C}$. Add ECL chemiluminescence reagent, reaction $1 \mathrm{~min}$ at room temperature, X-ray film exposure development, fixing. Protein expression was measured with Image J (National Institutes of Health, Bethesda, MD, USA). Relative target protein expression was normalised to $\beta$-actin.

\section{Statistical analysis}

Statistical analyses were performed using SPSS 19.0 software (IBM, Armonk, NY, USA). The data were expressed as mean \pm SEM. Statistical differences were evaluated by one-way analysis of variance (ANOVA). Correlation analyses were carried out using Pearson's correlation and Spearman's correlation analysis. Data with $P<0.05$ were considered statistically significant.

\section{Results \\ Pathological changes in the kidney from $\mathrm{CIH}$}

Both HE and PAS staining showed that there were no abnormalities in glomerular and renal tubular epithelial cell morphology in the control group. The renal tubular epithelial cells in the $4 \mathrm{w} \mathrm{CIH}$ group were moderately swollen, with sparse cytoplasm and tubule lumen was narrow. Some brush border of the tubules was lost while tubule dilatation, and the renal tubules were slightly damaged compared with those in the NC group $(p<$ $0.05)$. There were no obvious abnormalities in the glomerulus. The tubular epithelial cells in the $6 \mathrm{w} \mathrm{CIH}$ group were were future damaged $(\mathrm{p}<0.05)$, the damage included extensive tubule dilatation, loss of brush border, swelling and exfoliation of tubular epithelial cell, tubular epithelial cell exfoliation and the tubule dilatation were aggravated. The glomerulus was slightly swollen, and the balloon gap was somewhat narrow. The renal tubular epithelial cells in the $4 \mathrm{w} \mathrm{CIH}+\mathrm{Ri}$ group were more neatly arranged and less swollen than those in the $4 \mathrm{w}$ $\mathrm{CIH}$ group. The tubular damage scores were decreased compared with those of the $4 \mathrm{w} \mathrm{CIH}$ group $(p<0.05)$. The tubular epithelial cells in the $6 \mathrm{w} \mathrm{CIH}+\mathrm{Ri}$ group were less swollen than the $6 \mathrm{w} \mathrm{CIH}$ group, the loss of brush border and the tubule dilatation were reduced $(p<0.05)$. Meanwhile, the tubular damage scores were also decreased compared with those of the $6 \mathrm{w} \mathrm{CIH}$ group $(p<0.05)$ (Figs. 1, 2, 3). The results indicated that the $\mathrm{CIH}$ groups had significantly higher damage scores than the NC group, Ri decreased the tubular damage scores.

\section{Morphological changes of mitochondria}

The ultrastructural changes of mitochondria in tubules from biopsied samples were assessed by electron microscopy. Extensive structure alteration in renal tubular epithelial cells were seen in $\mathrm{CIH}$ environment, mainly manifested in mitochondrial fragments. There were much elongated and cylindrical mitochondria in NC group, whereas the majority of mitochondria were shorter and round in $\mathrm{CIH}$ groups. Obviously, these changes in $6 \mathrm{w} \mathrm{CIH}$ group were more serious than those in $4 \mathrm{w}$ CIH group $(P<0.05)$. After Ri treatment respectively, the mitochondrial fragments were reduced compared with those in $4 \mathrm{w} \mathrm{CIH}$ group and $6 \mathrm{w} \mathrm{CIH}$ group $(P<0.05)$ (Figs. 4, 5). These results suggested that Ri prevented the $\mathrm{CIH}$-induced mitochondrial fragmentation in morphology. 


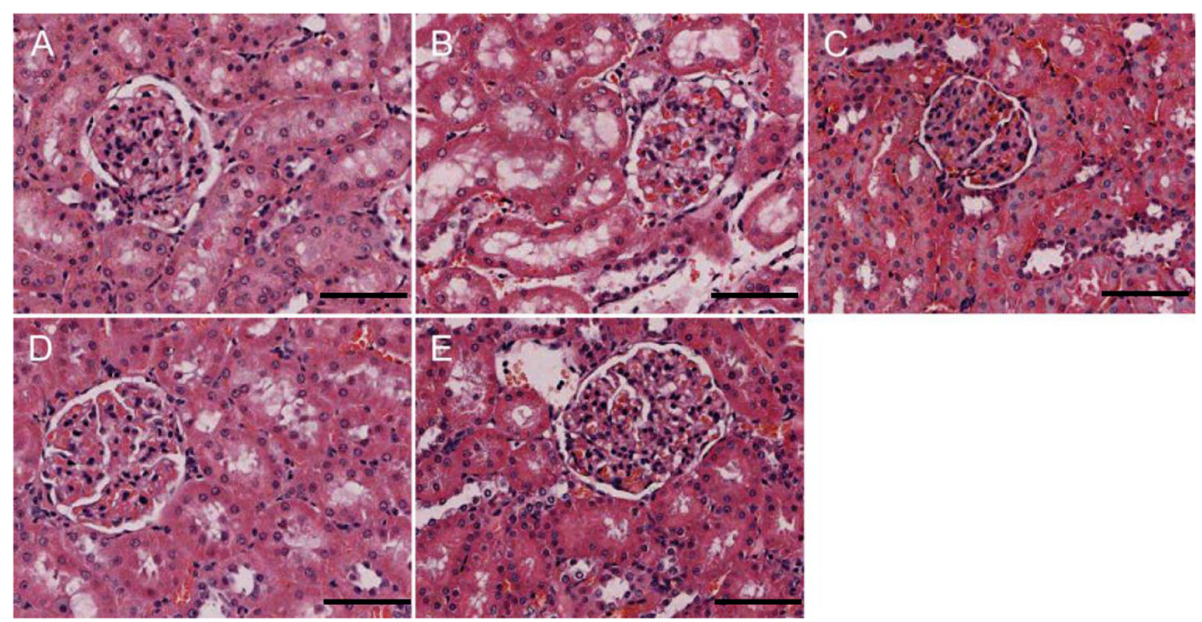

Fig. $1 \mathrm{ClH}$ causes renal damage. Changes in renal tissue morphology in each group were observed by HE staining. a: $\mathrm{NC} ; \mathbf{b}: 4 \mathrm{~W} \mathrm{ClH} ; \mathbf{c}: 6 \mathrm{~W} \mathrm{CIH} ; \mathbf{d}$ 4w ClH + Ri; e: $6 \mathrm{~W} \mathrm{ClH}+$ Ri. Original magnification, $\times 200$. Scale bars, $50 \mu \mathrm{m}$

\section{CB1R protein expression in rat renal tissue}

The results of immunohistochemistry and Western blotting demonstrated that CB1R expression in the renal tissue of 4 and 6w CIH groups was increased $(p<0.05)$, and the renal tubules in 4 and $6 \mathrm{w} \mathrm{CIH}$ groups were damaged. Compared with $4 \mathrm{w} \mathrm{CIH}$, the $\mathrm{CB1R}$ in renal tissue of rats exposed to $\mathrm{CIH} 6 \mathrm{w}$ was further increased $(p<0.05)$ and the renal injury was more serious. After treatment with the CB1R antagonist $\mathrm{Ri}$, the level of CB1R was significantly lower than that of $\mathrm{CIH}$ groups $(p<0.05)$, and the injury of renal tissue was also alleviated (Figs. 6, 7, 8, and 12a, a). The results showed that $\mathrm{Ri}$ could reduce the increase of CB1R induced by $\mathrm{CIH}$, and thus alleviate the kidney injury.

\section{Fis1/p66Shc/Mfn1 protein expression in rat renal tissue} Western blotting analyses and immunohistochemistry showed that Fis1 and p66Shc were expressed in the glomeruli and tubules of each group. The cytoplasm was yellowish or brown under the light microscope. In the control group, there was little expression in the glomeruli and tubules. Fis1 and p66Shc protein were significantly increased in $\mathrm{CIH}$ group renal tubules, with the highest expression in the $6 \mathrm{w} \mathrm{CIH}$ group. Compared with the $4 \mathrm{w} \mathrm{CIH}$ group, Fis1 and p66Shc protein expression in the $4 \mathrm{w} \mathrm{CIH} \mathrm{+} \mathrm{Ri}$ intervention group were significantly decreased $(p<0.05)$ and when compared with the $6 \mathrm{w}$ $\mathrm{CIH}$ group, Fis1 and p66Shc protein expression were significantly decreased $(p<0.05)$ in the $6 \mathrm{w} \mathrm{CIH}+\mathrm{Ri}$ group (Figs. 6, 7, 9, 10, 12b, c, b and c).

Western blotting analyses and immunohistochemistry also showed that Mfn1 was expressed in the glomeruli and tubules of each group of rats, and the cytoplasm of each group was light yellow or brown. In the control group, there was high Mfn1 expression in the glomeruli

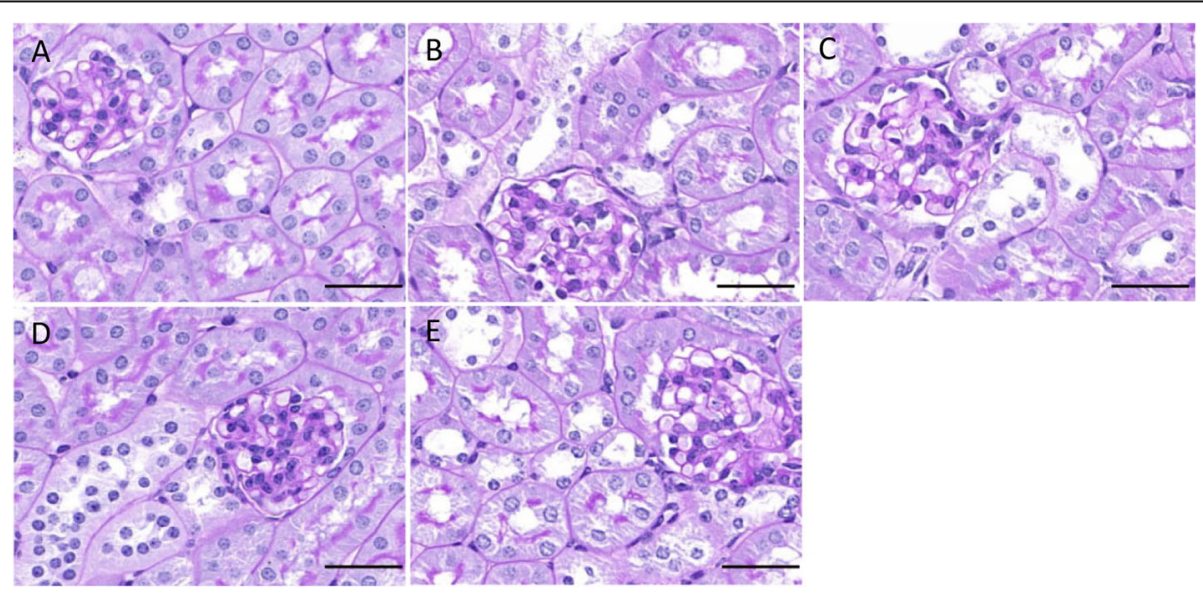

Fig. $2 \mathrm{CIH}$ causes renal damage. Changes in renal tissue morphology in each group were observed by $\mathrm{PAS}$ staining. a: $\mathrm{NC}$; b: $4 \mathrm{~W} \mathrm{CIH}$; $\mathbf{c}$ : $6 \mathrm{~W} \mathrm{CIH}$; d: $4 \mathrm{w} \mathrm{ClH}+\mathrm{Ri}$; e: $6 \mathrm{w} \mathrm{ClH}+\mathrm{Ri}$. Original magnification, $\times 200$. Scale bars, $50 \mu \mathrm{m}$ 


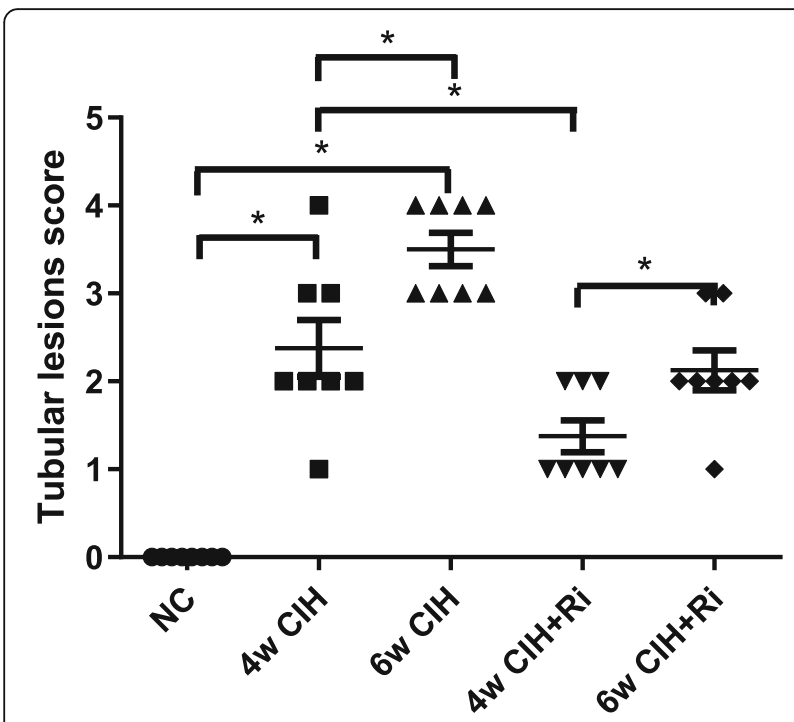

Fig. 3 Tubular lesions score. Histopathological scoring was performed and data are expressed as means \pm SEM, $n=8,{ }^{*} p<0.05$

and tubules. Mfn1 protein expression in renal tubules was significantly decreased $(p<0.05)$ in the 4 or $6 \mathrm{w}$ $\mathrm{CIH}$ group, with the lowest expression in the $6 \mathrm{w} \mathrm{CIH}$ group. Compared with the $4 \mathrm{w} \mathrm{CIH}$ group, Mfn1 protein expression in the $4 \mathrm{w} \mathrm{CIH}+\mathrm{Ri}$ group was significantly increased $(p<0.05)$ and when compared with the $6 \mathrm{w} \mathrm{CIH}$ group, Mfn1 protein expression in the 6w $\mathrm{CIH}+\mathrm{Ri}$ group was significantly $\operatorname{increased}(p<$ 0.05) (Figs. 6, 7, 11 and 12d, d).

These results suggest that Ri not only alleviated the morphological fragment in kidney which induced by $\mathrm{CIH}$, but also changed the expression of mitochondrial dynamics proteins Fis1, p66Shc and Mfn1 in CIH model, ultimately reduced $\mathrm{CIH}$-induced renal injury.

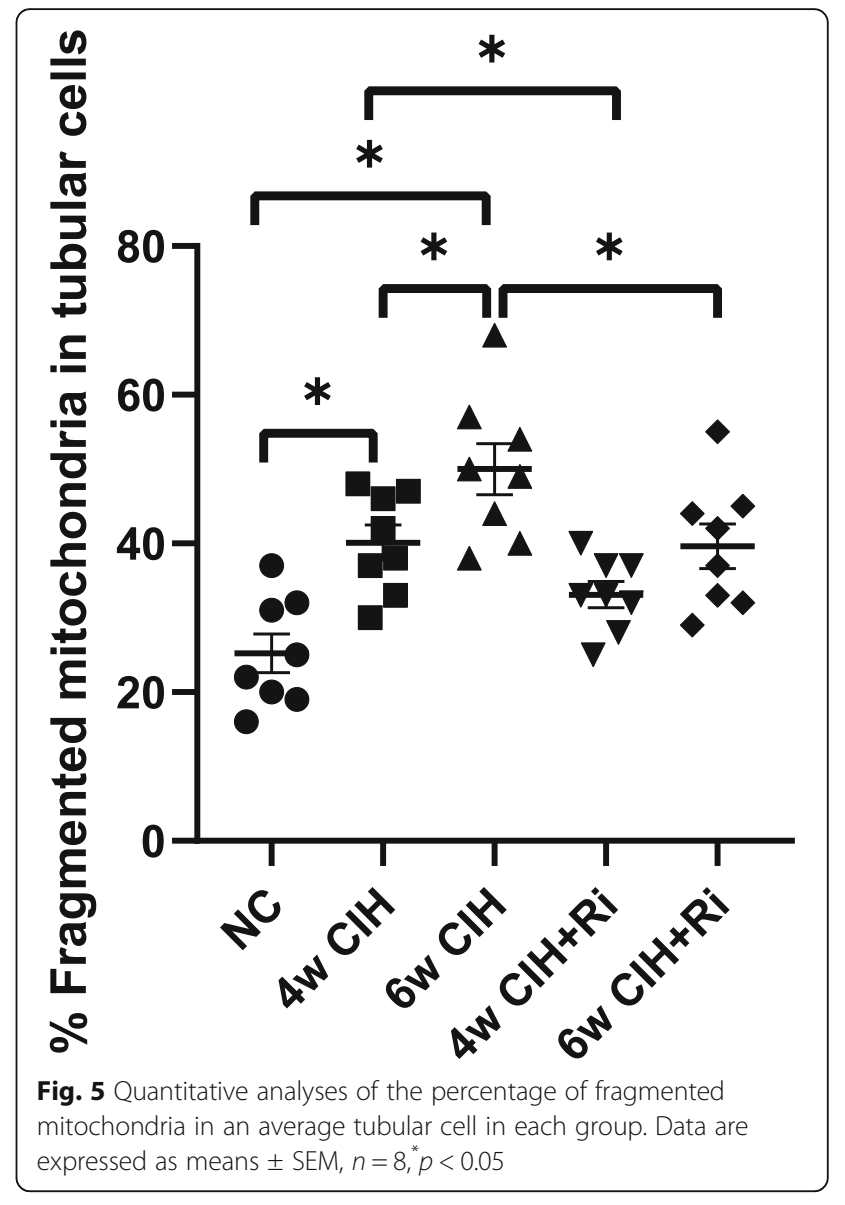

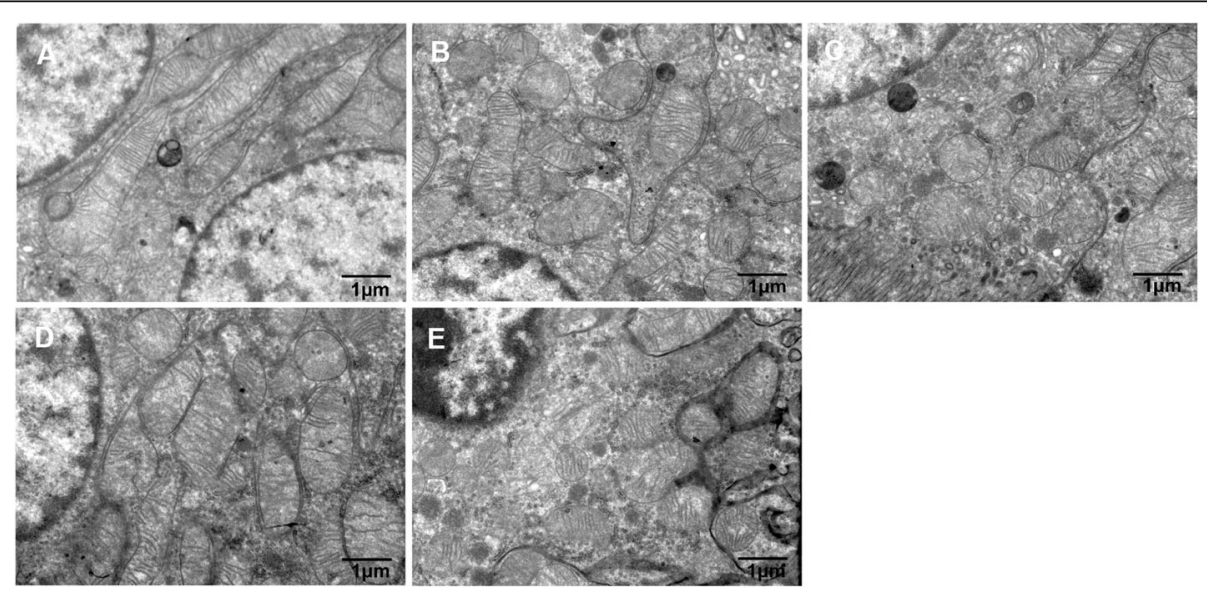

Fig. 4 Mitochondrial ultrastructural changes in tubular epithelial cells. Representative pictures of Mitochondrial electron microscopy. a: NC; b: $4 \mathrm{w}$ $\mathrm{ClH}$; c: $6 \mathrm{w} \mathrm{ClH}$; d: 4w ClH + Ri; e: $6 \mathrm{w} \mathrm{ClH}+$ Ri. Original magnification, $\times 10,000$. Scale bars, $1 \mu \mathrm{m}$ 


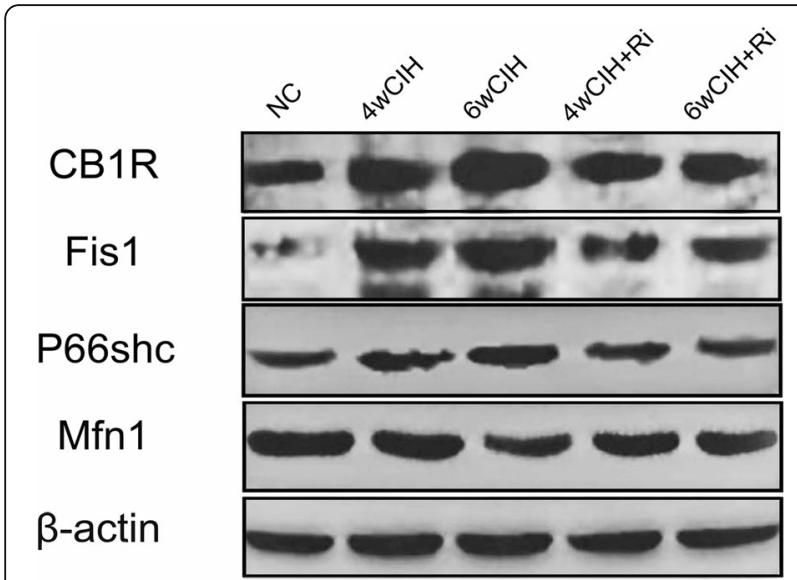

Fig. 6 Representative westem blotting images of CB1R, Fis1, p66shc and Mfn1 in renal tissue. Full-length blots are presented in Supplementary Figs. [1, 2, 3, 4, 5]

\section{Correlation comparison}

Pearson correlation analysis showed a positive correlation between CB1R and Fis1 expression $\left(R^{2}=0.797, p<\right.$ $0.01)$, and CB1R and p66shc $\left(R^{2}=0.659, p<0.01\right)$. Furthermore, CB1R and Mfn1 were negatively correlated $\left(R^{2}=-0.737, p<0.01\right.$; see Table 1$)$.

\section{Discussion}

$\mathrm{CIH}$ is the foremost pathophysiological change of OSA, and contributes to continued renal function deterioration. We used a $\mathrm{CIH}$ rat model to simulate the OSA pathophysiologic processes, and observed that $\mathrm{CIH}$ induced serious renal structure damage in the $\mathrm{CIH}$ group. This damage included extensive tubule dilatation, loss of brush border, swelling and exfoliation of tubular epithelial cell. The degree of abnormal changes in renal tissue is associated to $\mathrm{CIH}$ in a time-dependant manner.
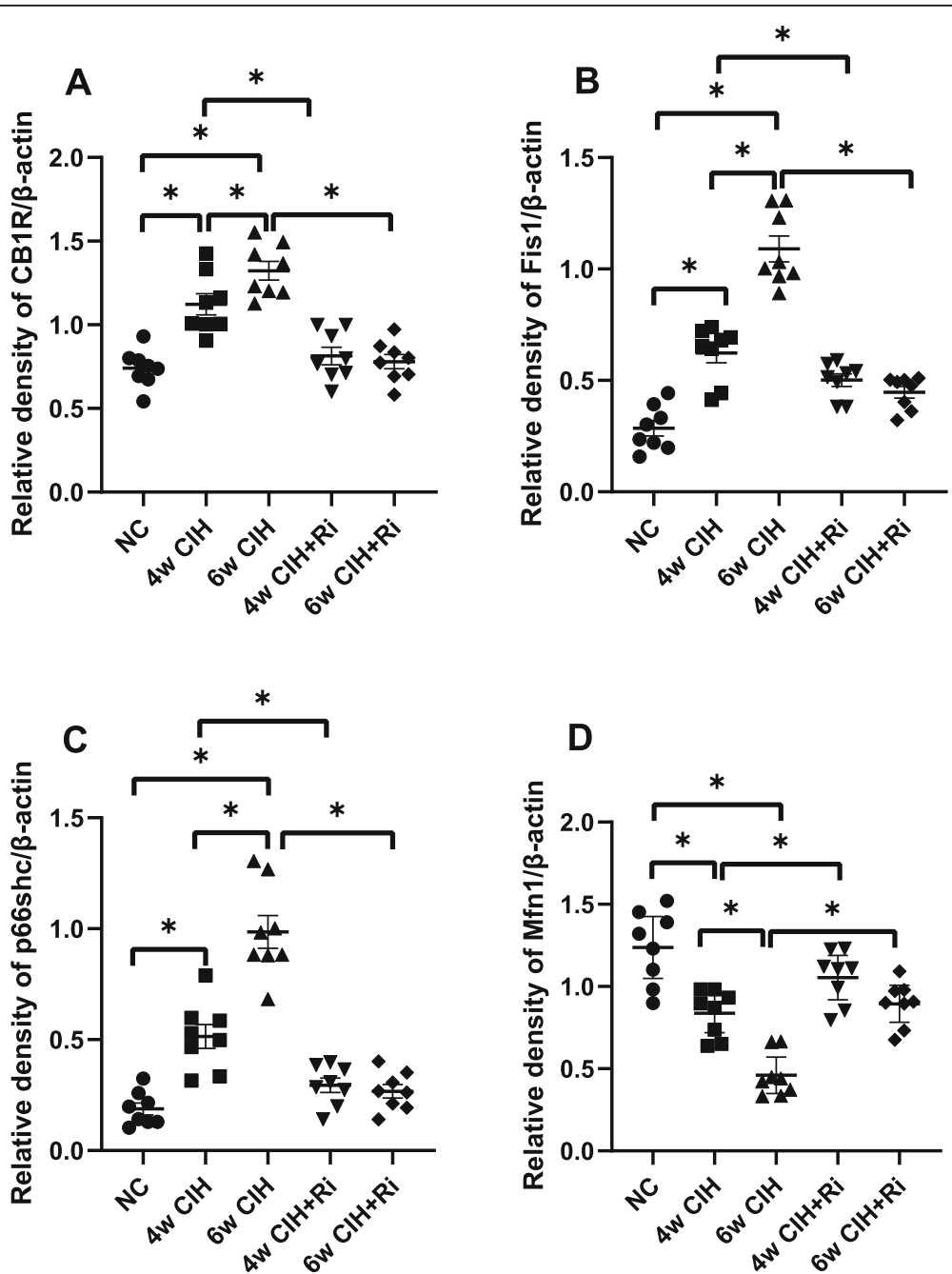

Fig. 7 Western blot analyses of CB1R, Fis1, p66shc and Mfn1 levels and normalized to $\beta$-actin. Protein expression was measured with Image J. Data are expressed as means \pm SEM $, n=8, p<0.001$. a: Relative density of CB1R/ $\beta$-actin; b: Relative density of Fis $1 / \beta$-acti; $\mathbf{c}$ : Relative density of p66shc/ $\beta$-actin; $\mathbf{d}$ : Relative density of Mfn $1 / \beta$-actin 


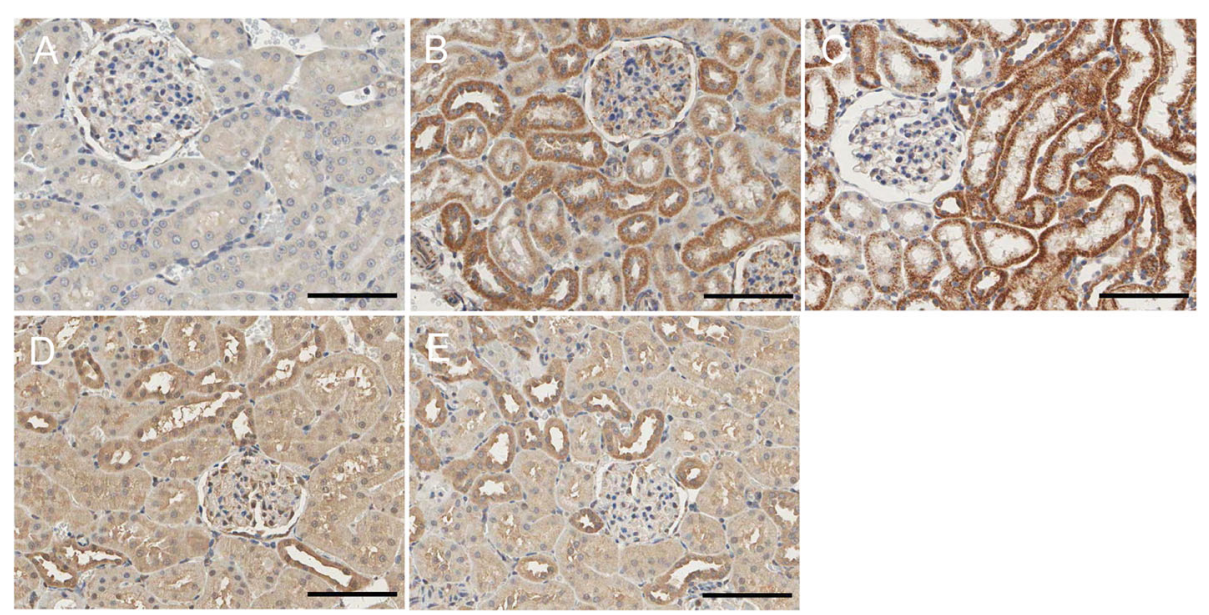

Fig. $8 \mathrm{CIH}$ increases renal CB1R levels, which are attenuated by rimonabant. CB1R immunohistochemistry in renal tissue in each group. a: NC; $\mathbf{b}$ $4 \mathrm{w} \mathrm{CIH} ; \mathbf{c}: 6 \mathrm{w} \mathrm{ClH} ; \mathbf{d}: 4 \mathrm{w} \mathrm{ClH}+\mathrm{Ri} ; \mathbf{e :} 6 \mathrm{w} \mathrm{ClH}+$ Ri. Original magnification, $\times 200$. Scale bars, $50 \mu \mathrm{m}$

Moreover, Ri notably alleviated these morphological changes, indicating that renal injury was significantly hampered in the $\mathrm{CIH}+\mathrm{Ri}$ groups. Therefore, we conclude that pathological changes from OSA in CIH may cause pathological changes in renal tissue.

EC disorders were detected in OSA patients in early clinical studies [32, 33], which include CB1R overexpression. Furthermore, many enzymes that synthesize ECs were increased in these patients. CB1R is often used to detect changes in EC system function. In this study, $\mathrm{CB} 1 \mathrm{R}$ is expressed in renal tissue. Compared with normal tissue, CB1R expression was increased in the $\mathrm{CIH}$ groups in a time-dependent manner; however, Ri reduced CB1R expression in both $\mathrm{CIH}$ groups. There were no obvious changes among NC groups. Thus, we conclude that $\mathrm{CIH}$ increases $\mathrm{CB} 1 \mathrm{R}$ expression in renal tissues, and that the expression level is related to hypoxia duration and intervention.

Recently, mitochondrial dynamics in various kidney diseases have been extensively investigated. Current reports mainly focus on diabetic kidney disease, renal ischaemia-reperfusion injury, and drug-induced or heavy-metal nephropathy. Studies have shown that the expression of mitochondrial dynamic proteins, Drp1 and Fis1, are upregulated, while Mfn1 expression is downregulated in early-stage renal disease. These alterations induce changes in mitochondrial morphology and dynamics, cause mitochondrial fragmentation, promote mitochondrial dysfunction, and lead to oxidative damage and apoptosis [34-39]. Interestingly, p66Shc is a master

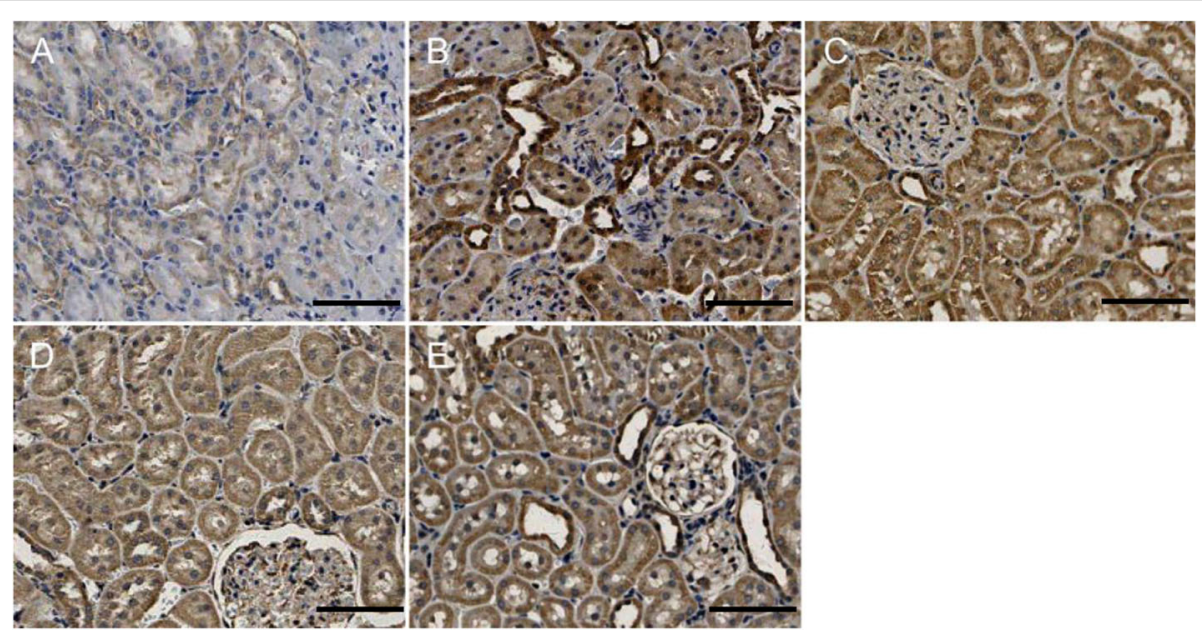

Fig. 9 Fis 1 protein expression in rat renal tissue. Immunohistochemical labelling of Fis 1 in renal tissue in each group. a $\mathrm{NC} ; \mathbf{b}: 4 \mathrm{~W} \mathrm{ClH} ; \mathbf{c}: 6 \mathrm{~W} \mathrm{ClH}$; d: $4 \mathrm{w} \mathrm{CIH}+\mathrm{Ri}$; e: $6 \mathrm{~W} \mathrm{ClH}+$ Ri. Original magnification, $\times 200$. Scale bars, $50 \mu \mathrm{m}$ 


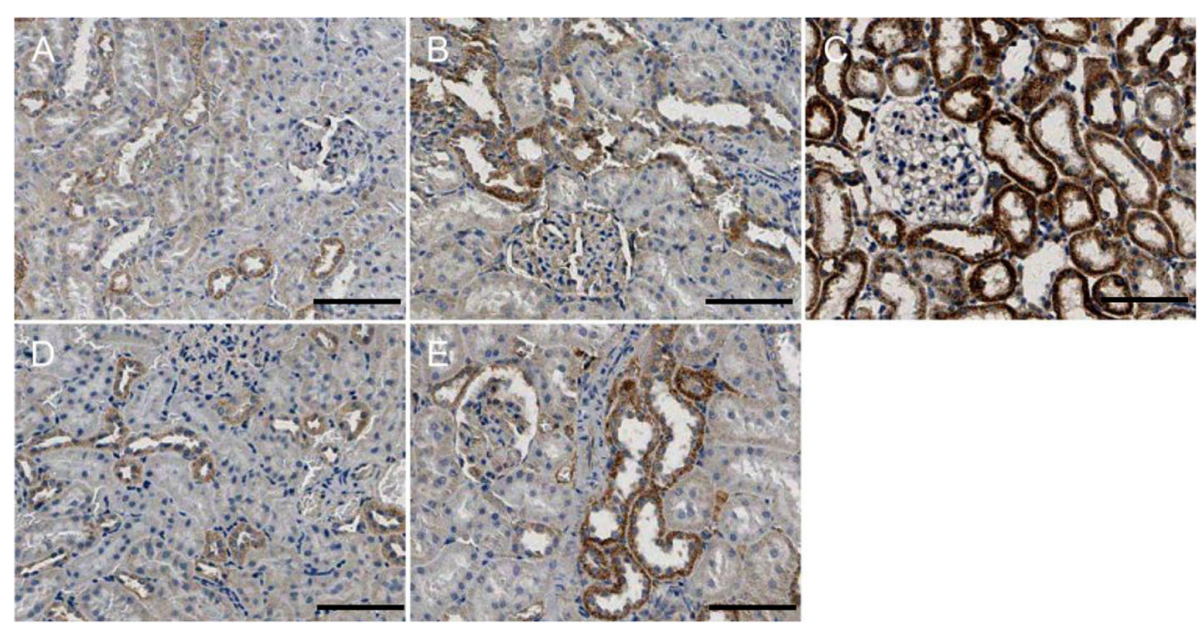

Fig. 10 P66shc protein expression in rat renal tissue. Immunohistochemical labelling of p66shc in renal tissue in each group. a: $N C ; \mathbf{b}: 4 \mathrm{w} C \mathrm{H} ; \mathbf{c}$ : $6 \mathrm{w} \mathrm{ClH;} \mathrm{d:} \mathrm{4w} \mathrm{ClH} \mathrm{+} \mathrm{Ri;} \mathrm{e:} 6 \mathrm{w} \mathrm{ClH}+$ Ri. Original magnification, $\times 200$. Scale bars, $50 \mu \mathrm{m}$

regulator of mitochondrial ROS, apoptosis, and lifespan in mammals, and is involved in several diseases, particularly aging and metabolic disorders [40]. Following the induction of stress, p66Shc is activated and phosphorylated in the cytosol, inducing translocation to the mitochondrial inter-membrane space, where it binds and oxidizes cytochrome $\mathrm{C}$ to generate excessive ROS $\left(\mathrm{H}_{2} \mathrm{O}_{2}\right)$ that leads to apoptosis $[41,42]$. These results link p66Shc to mitochondrial dynamics and apoptosis in tubular cells in diabetic nephropathy, and identify a novel mechanism underlying the redox-regulating and pro-apoptotic effects of p66Shc. In this study, we observed that p66Shc, Fis1, and Mfnl are expressed in renal tubular epithelial cells. p66Shc and Fis1 expression was significantly increased in the $\mathrm{CIH}$ group, while Mfnl expression was significantly decreased. Excitingly, the electron microscope also showed that mitochondria of renal tubular epithelial cells were widely fragmented in $\mathrm{CIH}$ environment, the degree of mitochondrial fragmentation depended on the duration of $\mathrm{CIH}$. The results indicate that abnormal mitochondrial dynamics may participate in $\mathrm{CIH}$-induced kidney disease progression, and the expression of p66Shc, Fis1 and Mfn1 is closely related to disease severity. Besides, we observed that p66Shc, Fis1, and Mfnl expression were closely related to CB1R expression. Further, Ri increased Mfnl expression, decreased Fis1 and p66Shc expression, alleviated the over division of mitochondria, and ameliorated renal tissue injury. These results suggest that CB1R activation leads to mitochondrial fragmentation, and that $\mathrm{Ri}$ reduces $\mathrm{CIH}$-induced renal damage by inhibiting altered mitochondrial dynamics.

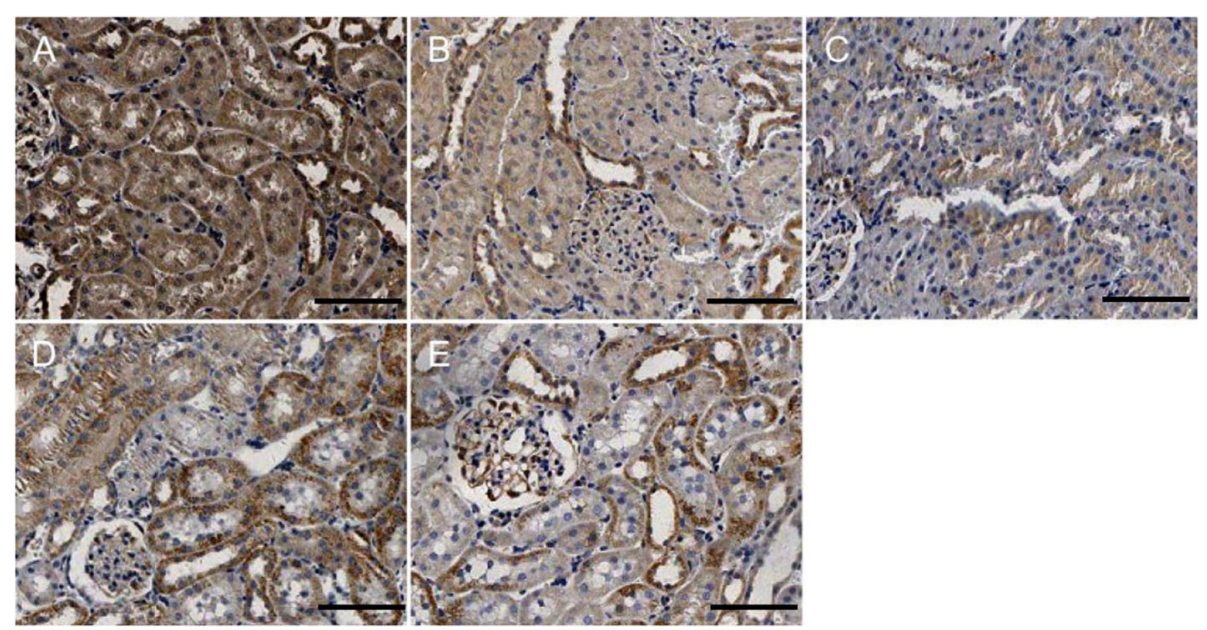

Fig. $11 \mathrm{Mfn} 1$ protein expression in rat renal tissue. Immunohistochemical labelling of Mfn1 in renal tissue in each group. a: $\mathrm{NC} ; \mathbf{b}: 4 \mathrm{~W} \mathrm{ClH} ; \mathbf{c}: 6 \mathrm{~W}$ $\mathrm{ClH}$; d: 4w ClH + Ri; e: $6 \mathrm{w} \mathrm{ClH}+$ Ri. Original magnification, $\times 200$. Scale bars, $50 \mu \mathrm{m}$ 

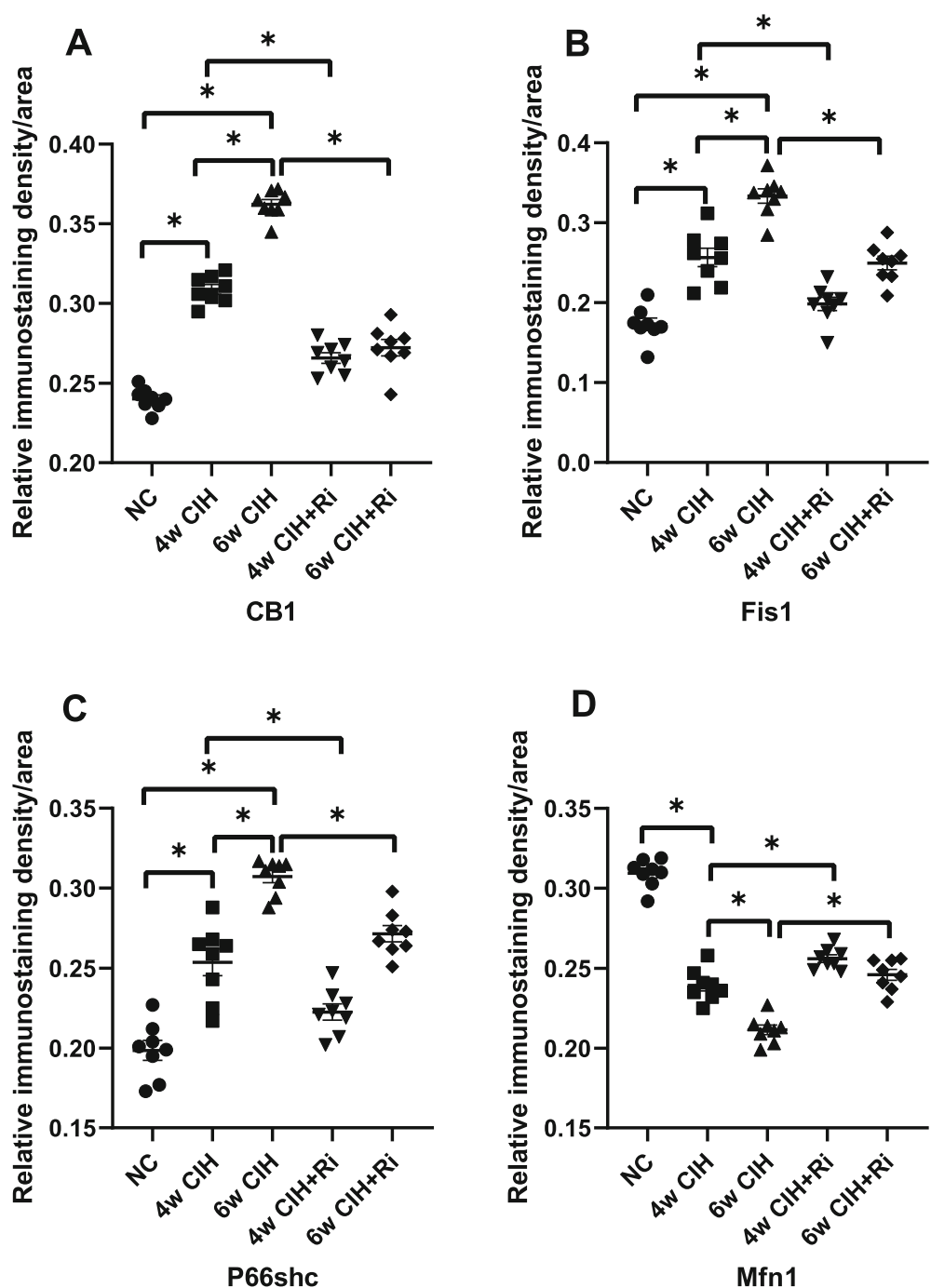

Fig. 12 Quantitative analyses of CB1R, Fis1, p66shc and Mfn1 using immunohistochemistry. Data are expressed as means $\pm S E M, n=8,{ }^{*} p<0.05$. a: Relative immunostatining density of CB1R/aera; $\mathbf{b}$ : Relative immunostaining density of Fis1/area; c: Relative immunostaining density of P66shc/ area; d: Relative immunostatining density of Mfn1/area

In conclusion, we demonstrate that $\mathrm{CIH}$ caused by OSA could trigger EC system disorders, resulting in renal injury. Further, our results indicate that $\mathrm{CIH}$ increases CB1R expression, which increases p66Shc and induces mitochondrial dynamic alterations by disrupting fission-fusion machinery. This disruption can result in the loss of mitochondrial membrane potential, cytochrome $\mathrm{C}$ release, and consequent

Table 1 Correlation between CB1R expression and Fis1, p66shc and Mfn1 levels

\begin{tabular}{lll}
\hline Index & $\mathbf{R}^{2}$-value & $\boldsymbol{p}$-value \\
\hline Fis1 & 0.797 & $p<0.01$ \\
p66shc & 0.659 & $p<0.01$ \\
Mfn1 & -0.737 & $p<0.01$ \\
\hline
\end{tabular}

oxidative stress and apoptosis [22]. After using CB1R antagonists, CB1R expression decreases, indicating restored mitochondrial dynamics, which further improved the renal damage. These results indicate that CB1R plays a role in renal injury caused by $\mathrm{CIH}$, and $\mathrm{CB} 1 \mathrm{R}$ inhibition decreases the risk of $\mathrm{CIH}$ patients from developing EC system disorders. Thus, the EC system could be a therapeutic target to ameliorate renal injury caused by OSA. However, neither did we study the changes in CB1R and renal tissue under different hypoxia conditions, nor any dose-dependent protective effects of $\mathrm{Ri}$ on $\mathrm{CIH}$-induced renal injury in our animal study. Hence, these components warrant further investigated in future studies.

\section{Abbreviations}

CB1R: Cannabinoid receptor 1; CIH: Chronic intermittent hypoxia;

CKD: Chronic kidney disease; EC: Endocannabinoid; $\mathrm{FiO}_{2}$ : Fraction of inspired 
oxygen; NC: Normal control; OSA: Obstructive sleep apnoea; Ri: Rimonabant; ROS: Reactive oxygen species

\section{Supplementary Information}

The online version contains supplementary material available at https:/doi. org/10.1186/s12882-021-02362-6.

Additional file 1: Figure S1. Representative western blotting images of CB1R in renal tissue. Figure S2. Representative western blotting images of Fis1 in renal tissue. Figure $\mathbf{S 3}$. Representative western blotting images of p66shc in renal tissue. Figure S4. Representative western blotting images of Mfn1 in renal tissue. Figure S5. Representative western blotting images of $\beta$ - actin.

\section{Acknowledgements}

Not applicable.

\section{Authors' contributions}

B.W. study design; L.Z. experiment conduct, data analysis and writing the manuscript; T.L. and M.W. experimental procedures; Z.D.and Z. H. data analysis. All authors read and approved the final manuscript.

\section{Funding}

This study was supported in part by grants from the National Natural Science Foundation of China (No. 81570086) and the key research and development plan of Shanxi Province(No. 201903D321137).

\section{Availability of data and materials}

The datasets used and /or analyzed in the current study are available from the corresponding author on reasonable request.

\section{Declarations}

\section{Ethics approval and consent to participate}

The project was approved by the Ethics Committee of the Science and Technology Department of The Second Hospital of Shanxi Medical University, China and implemented in accordance with regulations of the People's Republic of China on Animal Management. The study was carried out in compliance with the ARRIVE guidelines.

\section{Consent for publication}

Not applicable.

\section{Competing interests}

The authors declare that they have no competing interests.

\section{Author details}

'Shanxi Medical University, No. 56, Xijian South Road, Taiyuan 030001, Shanxi, People's Republic of China. ${ }^{2}$ The Second Hospital of Shanxi Medical University, No. 382, Wuyi Road, Taiyuan 030001, Shanxi Province, People's Republic of China.

\section{Received: 29 September 2020 Accepted: 14 April 2021}

\section{Published online: 26 April 2021}

\section{References}

1. Benjafield A, Ayas NT, Eastwood PR, Heinzer R, Ip MSM, Morrell MJ, et al. Estimation of the global prevalence and burden of obstructive sleep apnoea: a literature-based analysis. Lancet Respir Med. 2019;7(8):687-98. https://doi.org/10.1016/s2213-2600

2. Toraldo DM, De Nuccio F, De Benedetto M, Scoditti E. Obstructive sleep apnoea syndrome: a new paradigm by chronic nocturnal intermittent hypoxia and sleep disruption. Acta Otorhinolaryngol Ital. 2015;35(2):69-74

3. Lavie L. Oxidative stress in obstructive sleep apnea and intermittent hypoxia- revisited-the bad ugly and good: implications to the heart and brain. Sleep Med Rev. 2015;20:27-45. https://doi.org/10.1016/.smrv.2014. 07.003 .
4. Dewan NA, Nieto FJ, Somers VK. Intermittent hypoxemia and OSA: implications for comorbidities. Chest. 2015;147(1):266-74. https://doi.org/1 0.1378/chest.14-0500.

5. Somers VK, White DP, Amin R, Abraham WT, Costa F, Culebras A, et al. Sleep apnea and cardiovascular disease. Circulation. 2008;118(10):1080-11. https:// doi.org/10.1161/CIRCULATIONAHA.107.189420.

6. Dempsey JA, Veasey SC, Morgan BJ, O'Donnell CP. Pathophysiology of sleep apnea. Physiol Rev. 2010;90(1):47-112. https://doi.org/10.1152/physrev. 00043.2008

7. Andrade AG, Bubu OM, Varga AW, Osorio RS. The relationship between obstructive sleep apnea and Alzheimer's disease. J Alzheimers Dis. 2018; 64(s1):S255-S70. https://doi.org/10.3233/JAD-179936.

8. Sheu JJ, Lee HC, Lin HC, Kao LT, Chung SD. A 5-year follow-up study on the relationship between obstructive sleep apnea and Parkinson disease. J Clin Sleep Med. 2015:15(1112):1403-8. https://doi.org/10.5664/jcsm.5274.

9. Alonso-Fernández $A$, de la Peña M, Romero D, Piérola J, Piérola J, Carrera M, et al. Association between obstructive sleep apnea and pulmonary embolism. Mayo Clin Proc. 2013;88(6):579-87. https://doi.org/10.1016/j.ma yocp.2013.02.005.10.

10. Sim JJ, Rasgon SA, Kujubu DA, Kumar VA, Liu ILA, Shi JM, et al. Sleep apnea in early and advanced chronic kidney disease: Kaiser Permanente Southern California cohort. Chest. 2009;135(3):710-6. https://doi.org/10.1378/chest. 08-2248.

11. Hanly PJ, Ahmed SB. Sleep apnea and the kidney: is sleep apnea a risk factor for chronic kidney disease? Chest. 2014;146(4):1114-22. https://doi. org/10.1378/chest.14-0596.

12. Adams RJ, Appleton SL, Vakulin A, Hanly PJ, McDonald SP, Martin SA, et al. Chronic kidney disease and sleep apnea association of kidney disease with obstructive sleep apnea in a population study of men. Sleep. 2017:40. https://doi.org/10.1093/sleep/zsw015.

13. Zhu WZ, Wu XF, Zhang Y, Zhou ZN. Proteomic analysis of mitochondrial proteins in cardiomyocytes from rats subjected to intermittent hypoxia. Eur J Appl Physiol. 2012;112(3):1037-46. https://doi.org/10.1007/s00421-011-2 050-9.

14. Sharma K, Karl B, Mathew AV, Gangoiti JA, Wassel CL, Saito R, et al. Metabolomics reveals signature of mitochondrial dysfunction in diabetic kidney disease. J Am Soc Nephrol. 2013;24(11):1901-12. https://doi.org/10.1 681/ASN.2013020126.

15. Zhan M, Brooks C, Liu F, Sun L, Dong Z. Mitochondrial dynamics: regulatory mechanisms and emerging role in renal pathophysiology. Kidney Int. 2013; 83(4):568-81. https://doi.org/10.1038/ki.2012.441.

16. Galvan DL, Green NH, Danesh FR. The hallmarks of mitochondrial dysfunction in chronic kidney disease. Kidney Int. 2017;92(5):1051-7. https:// doi.org/10.1016/j.kint.2017.05.034

17. Liochev SI. Reactive oxygen species and the free radical theory of aging FreeRadic Biol Med. 2013;60:1-4. https://doi.org/10.1016/j.freeradbiomed.2 013.02.011.

18. Guo C, Wilkinson KA, Evans AJ, Rubin PP, Henley JM. SENP3-mediated deSUMOylation of Drp1 facilitates interaction with Mff to promote cell death. Sci Rep. 2017;7(1):43811. https://doi.org/10.1038/srep43811.

19. Menini S, Amadio L, Oddi G, Ricci C, Pesce C, Pugliese F, et al. Deletion of p66Shc longevity gene protects against experimental diabetic glomerulopathy by preventing diabetes-induced oxidative stress. Diabetes. 2006;55(6):1642-50. https://doi.org/10.2337/db05-1477.

20. Sun L, Xiao L, Nie J, Liu FY, Ling GH, Zhu XJ, et al. p66Shc mediates highglucose and angiotensin II-induced oxidative stress renal tubular injury via mitochondrial-dependent apoptotic pathway. Am J Physiol Renal Physiol. 2010;299(5):F1014-25. https://doi.org/10.1152/ajprenal.00414.2010.

21. Zhan M, Usman I, Yu J, Ruan L, Bian X, Yang J, et al. Perturbations in mitochondrial dynamics by p66Shc lead to renal tubular oxidative injury in human diabetic nephropathy. Clin Sci (Lond). 2018;132(12):1297-314. https://doi.org/10.1042/cs20180005.

22. Drori A, Permyakova A, Hadar R, Udi S, Nemirovski A, Tam J. Cannabinoid-1 receptor regulates mitochondrial dynamics and function in renal proximal tubular cells. Diabetes Obes Metab. 2019;21(1):146-59. https:/doi.org/10.1111/dom.13497.

23. Sharma C, Sadek B, Goyal SN, Sinha S, Kamal MA, Ojha S. Small molecules from nature targeting G-protein coupled cannabinoid receptors: potential leads for drug discovery and development. Evid Based Complement Alternat Med. 2015;238482:1-26. https://doi.org/10.1155/2015/238482.

24. McPartland JM, Guy GW, Di Marzo V. Care and feeding of the endocannabinoid system: a systematic review of potential clinical 
interventions that upregulate the endocannabinoid system. PLoS One. 2014 9(3):e89566. https://doi.org/10.1371/journal.pone.0089566.

25. Hryciw DH, McAinch AJ. Cannabinoid receptors in the kidney. Curr Opin Nephrol Hypertens. 2016;25(5):459-64. https://doi.org/10.1097/MNH. 0000000000000249 .

26. Barutta F, Corbelli A, Mastrocola R, Gambino R, Di Marzo V, Pinach S, et al. Cannabinoid receptor 1 blockade ameliorates albuminuria in experimental diabetic nephropathy. Diabetes. 2010;59(4):1046-54. https://doi.org/10.2337/ db09-1336.

27. Briffa JF, Grinfeld E, McAinch AJ, Poronnik P, Hryciw DH. Short term exposure to elevated levels of leptin reduces proximal tubule cell metabolic activity. Mol Cell Endocrinol. 2014;382(1):38-45. https://doi.org/10.1016/j. mce.2013.09.001

28. Lecru L, Desterke C, Grassin-Delyle S, Chatziantoniou C, Vandermeersch S, Devocelle $A$, et al. Cannabinoid receptor 1 is a major mediator of renal fibrosis. Kidney Int. 2015;88(1):72-84. https://doi.org/10.1038/ki.2015.63.

29. Calik MW, Carley DW. Effects of cannabinoid agonists and antagonists on sleep and breathing in Sprague-Dawley rats. Sleep. 2017;40(9). https://doi. org/10.1093/sleep/zsx112.

30. Dou ZJ, Gao XL, Jia YL, Chen J, Yang JJ, Chen Y, et al. CB1 receptor antagonist rimonabant protects against chronic intermittent hypoxiainduced bone metabolism disorder and destruction in rats. Sleep Breath 2020;24(4):1441-9. https://doi.org/10.1007/s11325-019-02009-9.

31. Melnikov VY, Faubel S, Siegmund B, Lucia MS, Ljubanvic D, Edelstein CL. Neutrophil-independent mechanisms of caspase-1- and IL-18-mediated ischemic acute tubular necrosis in mice. J Clin Invest. 2002;110(8):1083-91. https://doi.org/10.1172/JC115623.

32. Wang X, Yu Q, Yue H, Zhang J, Zeng S, Cui F. Circulating endocannabinoids and insulin resistance in patients with obstructive sleep apnea. Biomed Res Int. 2016;9782031:1-8. https://doi.org/10.1155/2016/9782031.

33. Baker MJ, Lampe PA, Stojanovski D, Korwitz A, Anand R, Tatsuta T, et al. Stress-induced OMA1 activation and autocatalytic turnover regulate OPA1dependent mitochondrial dynamics. EMBO J. 2014;33(6):578-93. https://doi. org/10.1002/embj.201386474

34. Molina AJ, Wikstrom JD, Stiles L, Las G, Mohamed H, Elorza A, et al. Mitochondrial networking protects beta-cells from nutrient-induced apoptosis. Diabetes. 2009:58(10):2303-15. https://doi.org/10.2337/db07-1781.

35. Westermann B. Mitochondrial fusion and fission in cell life and death. Nat Rev Mol Cell Biol. 2010:11(12):872-84. https://doi.org/10.1038/nrm3013.

36. Kanfer G, Kornmann B. Dynamics of the mitochondrial network during mitosis. Biochem Soc Trans. 2016;44(2):510-6. https://doi.org/10.1042/BST2 0150274.

37. Hu Z, Cheng J, Xu J, Ruf W, Lockwood CJ. Tissue factor is an angiogenicspecific receptor for factor VII-targeted immunotherapy and photodynamic therapy. Angiogenesis. 2017;20(1):85-96. https://doi.org/10.1007/s10456-0169530-9.

38. Rienks M, Carai P, Bitsch N, Schellings M, Vanhaverbeke M, Verjans J, et al. Sema3A promotes the resolution of cardiac inflammation after myocardial infarction. Basic Res Cardiol. 2017;112(4):42. https://doi.org/10.1007/s00395017-0630-5.

39. Gertz M, Fischer F, Leipelt M, Wolters D, Steegborn C. Identification of eroxiredoxin 1 as a novel interaction partner for the lifespan regulator protein p66Shc. Aging (Albany NY). 2009;1 (2):254-65. https://doi.org/10.1 8632/aging.100017.

40. Gertz M, Steegborn C. The lifespan-regulator p66Shc in mitochondria: redox enzyme or redox sensor? Antioxid Redox Sign. 2010;13(9):1417-28. https:// doi.org/10.1089/ars.2010.3147.

41. Giorgio M, Migliaccio E, Orsini F, Paolucci D, Moroni M, Contursi C, et al. Electron transfer between cytochrome $\mathrm{C}$ and p66Shc generates reactive oxygen species that trigger mitochondrial apoptosis. Cell. 2005;122(2):22133. https://doi.org/10.1016/j.cell.2005.05.011.

42. Pinton P, Rimessi A, Marchi S, Orsini F, Migliaccio E, Giorgio M, et al. Protein kinase $\mathrm{C}$ beta and prolyl isomerase 1 regulate mitochondrial effects of the life-span determinant p66Shc. Science. 2007;315(5812):659-63. https://doi. org/10.1126/science.1135380.

\section{Publisher's Note}

Springer Nature remains neutral with regard to jurisdictional claims in published maps and institutional affiliations.

Ready to submit your research? Choose BMC and benefit from:

- fast, convenient online submission

- thorough peer review by experienced researchers in your field

- rapid publication on acceptance

- support for research data, including large and complex data types

- gold Open Access which fosters wider collaboration and increased citations

- maximum visibility for your research: over $100 \mathrm{M}$ website views per year

At BMC, research is always in progress.

Learn more biomedcentral.com/submissions 